\title{
Heimilislækningar á Íslandi í vanda
}

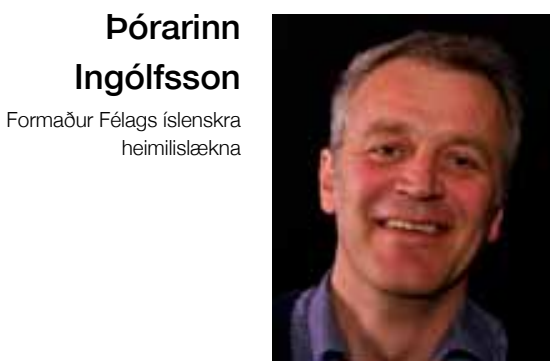

torarinn.ingolfsson@heilsugaeslan.is

Pegar ég var ungur læknir á Siglufirði árið 1991 með brennandi áhuga á heimilislækningum, kvaddi ég mér hljóðs á kosningafundi Jóns Baldvins og Sighvats Björgvinssonar á Hótel Höfn. Рað var augljóst að Sighvatur yrði heilbrigðisráðherra, enda handleggsbrotinn og prýddur forláta gifsumbúðum á handlegg. Ég mannaði mig upp og spurði pá félaga hvort Alpýðuflokkurinn ætti einhverja framtíðarstefnu í heilbrigðismálum. Pað varð fátt um svör og peir fóstbræður slógu pessu öllu upp í grín, enda var mjög gaman á fundinum. Sighvatur varð heilbrigðisráðherra og reyndi að koma á pjónustustýringu í heilbrigðiskerfinu en varð frá að hverfa með slíkar hugmyndir. Á pessum tíma var hver einasta staða heimilislæknis mönnuð, bæði í péttbýli og dreifbýli, og mikið hugsjónastarf unnið innan heimilislæknisfræðinnar. Í dag eru fjölmargar stöður á landsbyggðinni lausar og heilu landshlutarnir án fastra lækna. Nýlega voru 7 stöður sérfræðinga í heimilislækningum auglýstar í heilsugæslu höfuðborgarsvæðisins. Enginn sótti um. Við erum sem sagt enn í sömu sporum, heilbrigðisráðuneytið er nú deild í velferðarráðuneyti, enn olnbogabarn stjórnmálamanna með tíðum ráðherraskiptum, útgjaldadrýgsta ráðuneytið sem ekki virðist teljast nein upphefð í að stjórna.

Atburðarásin um og eftir efnahagshrun er hins vegar grafalvarleg. Heilbrigðisyfirvöld virðast í skjóli niðurskurðar vera á góðri leið með að ganga af heimilislækningum dauðum. Haustið 2007 var gerð reglugerðarbreyting sem skyldar heilsugæslustöðvarnar til að skrá fólk ,á heilsu- gæslustöð“ án heimilislæknis pó listar allra lækna par séu löngu yfirfullir og læknarnir hafi enga möguleika á að sinna pessu sem skyldi og er pannig grafið undan læknis/sjúklingssambandinu og pjónustunni sem veitt er. Pannig er vandinn falinn án pess аð koma með raunhæfar aðgerðir til að bregðast við heimilislæknaskorti.

Á vormánuðum 2010 var sagt upp samningi við 12 sjálfstætt starfandi heimilislækna sem sinna tugpúsundum skjólstæðinga og veita persónulega og góða pjónustu eftir hugmyndafræði heimilislækninga. Boðuð var á sama tíma starfræksla svokallaðrar "forvaktar" í samstarfi Landspítala og heilsugæslu höfuðborgarsvæðisins. Tilkynnt var einnig að samningur yrði ekki endurnýjaður við Læknavaktina sem veitir öllum sem pangað leita skjóta pjónustu sérfræðinga í heimilislækningum utan dagvinnutíma, hvort sem peir hafa skráðan heimilislækni eða ekki.

Boðuð var sameining og stækkun stöðva innan heilsugæslu höfuðborgarsvæðisins. Stækkun og samræming átti að koma í stað fjölbreytni og dreifstýringar. Ekkert var litið til reynslu nágrannapjóða eða annarra rekstrarforma sem hafa pó reynst vel og komið vel út úr pjónustukönnunum (Lágmúlastöðin, Salastöðin, sjálfstætt starfandi heimilislæknar).

Boðuð var samræming sem virtist pjóna hagsmunum stjórnsýslu stórfyrirtækisins en ekki pörfum íbúanna. Heimilislæknarnir sjálfir voru hins vegar ekki hafðir með í ráðum að neinu leyti, en samt vita peir best hvar skórinn kreppir að á sínu svæði, hvaða mannafla peir hafa yfir að ráða til að sinna pörfum sinna skjólstæðinga og hvernig á að forgangsraða verkefnum. Fagfélag heimilislækna hefur verið tilneytt til að verjast vondum hugmyndum frekar en að nýta fagpekkingu til að móta breytingar til framtíðar.

Heilsugæslan skiptist í tvö meginsvið, læknasvið og hjúkrunarsvið. Pessi tvö svið skarast vissulega. Hefðbundin hjúkrun er í góðum farvegi, mönnun viðunandi og aðgengi gott. Petta á við um ýmsa heilsuvernd, hjúkrunarmóttöku, ungbarnaeftir- lit og mæðravernd. Öðru máli gegnir um heimilislæknamóttökuna. Langflestir vilja hafa greiðan aðgang að heimilislækni. Lækni sem er hæfur og vel menntaður og pekkir til peirra og peir geta treyst fyrir sínum heilsufarsmálum, annaðhvort leyst úr peim eða komið peim í réttan farveg. Heimilislæknamóttakan er pjónusta sem fólk vill hafa í lagi. Pað er petta sem hugmyndafræði heimilislækninga gengur út á. Hugmyndafræði sem heimilislæknar hafa haldið á lofti síðustu áratugina. Á hinum Norðurlöndunum, par sem velferð er hvað próuðust í heiminum, forðast heilbrigðisyfirvöld miðstýringu í heimilislækningum. Best hefur reynst að láta heimilislæknana sjálfa bera ábyrgð á umsjá skjólstæðinga sinna, enda hafi peir mesta pekkingu á aðstæðum peirra og pörfum. Staðan er viðkvæm núna, heimilislæknar eru of fáir og margir yngri heimilislæknar hafa pegar hætt störfum og flust búferlum og peir sem eldri eru nálgast eftirlaun eða íhuga að draga sig í hlé eða fara í önnur verkefni. Ekki fást hæfir umsækjendur í stöður sem eru auglýstar.

Samningar við sérgreinalækna á stofum hafa ekki verið gerðir og fellur kostnaðarauki undanfarinna ára óskiptur á sjúklinga sem purfa á pjónustu peirra að halda. Pess eru mörg dæmi að fólk biðst undan tilvísun til sérfræðings vegna kostnaðar. Slíkt er óásættanlegt. Heilbrigðisyfirvöld purfa að viðurkenna að heilbrigðiskerfi Íslendinga eins og annarra próaðra pjóða hvílir á pekkingargrunni læknisfræðinnar. Læknar sem fagstétt verðskulda að haft sé samráð við pá um meiriháttar breytingar á heilbrigðiskerfinu. Tortryggni sú sem hefur verið leiðarljós yfirvalda undanfarinn áratug gagnvart fagfélögum lækna er óverðskulduð og hefur pegar valdið of miklum skaða.

Icelandic General Practice crisis

Thorarinn is a General Practitioner practicing in Reykjavik and president of the Icelandic College of General Practitioners. 